\title{
Heat-processed neoginseng, KG-135, down-regulates G1 Cyclin-dependent kinase through the proteasome-mediated pathway in HeLa cells
}

\author{
WON-HEE LEE ${ }^{1}$, JOON-SEOK CHOI ${ }^{1,2}$, HYUN YOUNG KIM ${ }^{3}$, JEONG-HILL PARK ${ }^{3}$, \\ SEUNG-KI LEE ${ }^{1,3}$ and YOUNG-JOON SURH ${ }^{3}$ \\ ${ }^{1}$ Division of Pharmaceutical Biosciences, ${ }^{2}$ BK21 Applied Pharmaceutical Sciences Research \\ Division, ${ }^{3}$ The Research Institute of Pharmaceutical Sciences, College of Pharmacy, \\ Seoul National University, Seoul 151-742, Korea
}

Received July 15, 2008; Accepted September 5, 2008

DOI: $10.3892 / o r \_00000246$

\begin{abstract}
High temperature heat treatment of ginseng (Panax ginseng, C.A. Meyer) generates KG-135 (heat-processed neoginseng) which contains a mixture of three major ginseng saponins, ginsenosides Rk1, Rg3 and Rg5. Ginsenosides, particularly of the diol-type including Rk1, Rg3 and Rg5, have been shown to induce cell growth arrest in various cell types of human cancer. Herein, we report that KG-135 is able to arrest the cell cycle in human cervix adenocarcinoma HeLa cells. KG-135 arrests cells at the G1 phase of the cell cycle with an $\mathrm{IC}_{50}$ value of $69 \mu \mathrm{g} / \mathrm{ml}$. The $\mathrm{G} 1$ phase arrest is associated with down-regulation of Cyclin D1/Cdk4 and Cyclin B1/Cdc2 activities in cells after treatment with KG-135. Furthermore, down-regulation of G1 Cyclin-dependent kinase activities is kinetically well related to the decreased intracellular protein levels of these kinases. In addition, the decrease in the levels of Cyclin D1/Cdk4 and Cyclin B1, but not of Cdc2, is similarly prevented by co-treatment of cells with MG-132, a potent proteasome inhibitor. Thus, the KG-135-induced arrest of the cell cycle at G1 phase in HeLa cells represents a novel mechanism that involves proteasome-mediated degradation of the Cyclins (Cyclin D1 and B1) and Cdk4 proteins.
\end{abstract}

\section{Introduction}

Progression of cell cycle in mammalian cells is driven by sequential activation of different members of the Cyclin and Cyclin-dependent kinase (Cdk) family. In human cancers, the activities of Cyclin/Cdk kinases are universally over-activated.

Correspondence to: Dr Y.-J. Surh, Division of Pharmaceutical Biosciences, College of Pharmacy, Seoul National University, Kwanak-gu, Seoul 151-742, Republic of Korea

E-mail: surh@plaza.snu.ac.kr

Key words: ginsenosides, G1 phase, Cyclin B1/Cdc2
Thus, cancer cells can be forced to undergo apoptotic cell death by arresting the cell cycle through Cdk inhibition (1). Progression of G1 is mainly controlled by Cyclin D/Cdk4 and Cyclin E/Cdk2 complexes and transition from G1 to S phase is governed by Cyclin $\mathrm{A} / \mathrm{Cdk} 2$, while $\mathrm{G} 2 / \mathrm{M}$ phase transition is mediated by the Cyclin $\mathrm{B} / \mathrm{Cdc} 2$ complex. These $\mathrm{Cyclin} / \mathrm{Cdk}$ activities are down-regulated by binding of $\mathrm{Cdk}$ inhibitor proteins (CKIs), p21 Waf1/Cip1 and p27 Kip1 (2-4). Thus, CKIs are thought to be good target molecules for controlling the cell cycle of cancer cells, and many investigators have been working to develop specific $\mathrm{Cdk}$ inhibitors and small peptide inhibitors from endogenous Cdk inhibitors of Cyclin/Cdk complexes (5).

Ginseng (Panax ginseng, C.A. Meyer) is one of the most widely used herbal medicines in Asian countries. There exists evidence supporting that some ginseng saponins (ginsenosides) have cytostatic or cytotoxic activities against various types of tumor cells in culture (6-9), including human hepatocarcinoma and cholangiocarcinoma cells $(10,11)$, human breast cancer cells (12), lung adenocarcinoma A549 cells (13), cervix cancer cells (14) and monocytic leukamia cells (15). In addition, chronic administration of ginseng has been reported to reduce the incidence of some cancers, such as esophageal, gastric, and colorectal, and pulmonary tumors $(16,17)$. Red ginseng is heat-processed ginseng and contains several specific ginsenosides that are not detected in white ginseng which is air-dried. These red-ginseng-specific ginsenosides have been shown to have more potent cytostatic or cytotoxic activity than other ginsenosides against various cancer cells $(18,19)$. In addition, 12-O-tetradecanoylphorbol13-acetate (TPA)-induced epidermal ornithine decarboxylase activity (ODC) and ODC mRNA expression were shown to be down-regulated by pretreatment of female ICR mice with a methanol extract of red ginseng (20). Moreover, TPA-induced production of tumor necrosis factor in the mouse skin was inhibited by pre-treatment with the same extract. Heat treatment of ginseng at a temperature higher than that applied to the conventional preparation of red ginseng generates KG-135, a mixture of ginsenosides that constitute about equal amounts of three ginsenosides, Rk1, Rg3 and Rg5. KG-135 has also been suggested to potently inhibit tumor promotion, an activity 
which appeared to be associated with its ability to suppress the inflammatory response in the human breast epithelial cell line, MCF-10A (21). The ginsenoside Rg3 was shown to inhibit TPA-induced cyclooxygenase- 2 expression, NF-кB activation and tumor promotion (22). In addition, ginsenoside $\mathrm{Rg} 5$ was suggested to down-regulate Cyclin E/ Cdk2 activity by a mechanism that decreases the intracellular levels of Cyclin E in SK-Hep1 cells (23). In this study, we investigated whether KG-135 specifically interfered with progression of the cell cycle through mechanisms that down-regulate Cyclindependent kinase activities in HeLa cells. Herein, we show that the cell cycle of HeLa cells is specifically arrested at G1 phase after treatment with KG-135. The KG-135-induced G1 arrest is associated with specific inhibition of activities of Cyclin D/Cdk4 and Cyclin B/Cdc2 kinases by a mechanism that involves degradation of Cyclin/Cdk complexes by proteasomes.

\section{Materials and methods}

Materials. A KG-135 stock solution of $75 \mathrm{mg} / \mathrm{ml}$ in DMSO was provided by Ginseng Science (Seoul, Korea). Dulbecco's modified Eagle's medium (DMEM) and fetal bovine serum (FBS) were obtained from Invitrogen (Grand Island, NY, USA) and $\left[\gamma^{-}{ }^{32} \mathrm{P}\right]$-labeled ATP was purchased from NEN ${ }^{\mathrm{TM}}$ Life Science Products, Inc. (Boston, MA, USA). Anti-p21 antibody was from Millipore (Billerica, MA, USA), and the other antibodies were from SantaCruz Biotechnology (SantaCruz, CA, USA). Easy-spin ${ }^{\mathrm{TM}}$ total RNA isolation kit and Maxime RT PreMix (Oligo(dT)15 Primer) were purchased from Intron Biotechnology (Gyeonggi Province, Korea). All other general drugs and chemicals were purchased from Sigma Chemical Co.

Cell culture and drug treatment. HeLa cells, derived from a squamous cell carcinoma of the cervix, were maintained as a monolayer culture in DMEM supplemented with 5\% (by volume) heat-inactivated fetal bovine serum (FBS) and $1 \%$ antibiotics and antimycotics mix, at $37^{\circ} \mathrm{C}$ in a humidified $5 \%$ $\mathrm{CO}_{2}$ atmosphere, and were fed every 3 days. Cells $\left(7 \times 10^{5}\right)$ (30\% confluency) were seeded on 100-mm diameter tissue culture plates (Nalge Nunc International, Denmark) and incubated. Twenty-four hours from seeding, KG-135 was introduced to HeLa cells. Floating and adherent cells were harvested using a cell scraper for the immunoblot analyses and histone $\mathrm{H} 1$ kinase assays. In co-treatment of KG-135 and MG-132, the cell culture was pre-treated with MG-132 for $3 \mathrm{~h}$ before KG-135 treatment.

MTT assay. The 3-(4,5-dimethylthiazol-2-yl)-2,5-diphenyltetrazolium bromide (MTT) assay was used to assess timeand dose-dependent cell growth inhibitory activity of KG-135. Cells were plated in 96-well plates and incubated for $24 \mathrm{~h}$ using the conditions for cell culture described above, then cells were treated with various concentrations of KG-135 for 12, 24 and $36 \mathrm{~h}$, respectively. After treatment, $15 \mu \mathrm{lof} 5 \mathrm{mg} / \mathrm{ml}$ MTT stock was added to each well, and the cells were incubated for $4 \mathrm{~h}$. MTT formazan was dissolved in $100 \mu \mathrm{l}$ of DMSO, and the absorbance of each well was measured at $570 \mathrm{~nm}$ of wavelength.

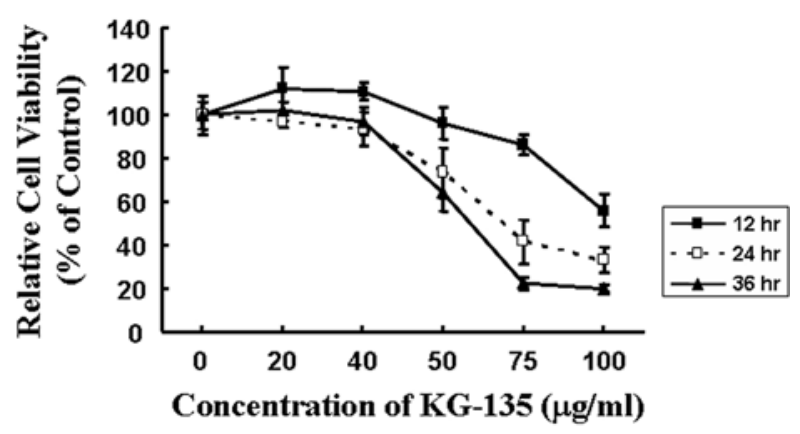

Figure 1. KG-135 shows growth inhibitory effect on HeLa cells. HeLa cells were incubated with KG-135 in DMEM containing 5\% FBS for intervals of $12 \mathrm{~h}$ for a period of $36 \mathrm{~h}$. Relative cell viability was determined by MTT assay as described in Materials and methods. Data are presented as the mean \pm standard deviation of individual triplicate experiments.

Flow cytometric analysis. HeLa cells were plated at a density of cells $\left(7 \times 10^{5}\right)$ per $100-\mathrm{mm}$ dish, cultured in DMEM containing 5\% FBS, and treated with $75 \mu \mathrm{g} / \mathrm{ml} \mathrm{KG-135} \mathrm{in}$ DMEM for intervals of $6 \mathrm{~h}$. Adherent and floating cells were trypsinized and fixed with $70 \%$ ethanol and stored at $4{ }^{\circ} \mathrm{C}$. Fixed cells were rehydrated with phosphate-buffered saline and suspended in staining solution containing $50 \mu \mathrm{g} / \mathrm{ml}$ propidium iodide and $100 \mu \mathrm{g} / \mathrm{ml}$ RNase A. Cell cycle analysis was performed using a flow cytometer (FACS calibur, BD). The percentage of cells in each phase of the cell cycle was analyzed by CellQuest ${ }^{\circledR}$ Pro software.

Immunoprecipitation and HI kinase assay. An aliquot $(200 \mu \mathrm{g})$ of protein from each cell extract was pre-cleared with protein A-agarose beads (Millipore, Billerica, MA, USA), and the supernatant was incubated with shaking for $4 \mathrm{~h}$ in an ice bath with polyclonal rabbit antibodies for each Cdk. Immunecomplexes associated with each Cdk were collected and washed 3 times with lysis buffer and twice with kinase assay buffer containing $50 \mathrm{mM}$ Tris ( $\mathrm{pH} 7.5$ ), $10 \mathrm{mM} \mathrm{MgCl} 2,1 \mathrm{mM}$ DTT, $1 \mathrm{mM}$ EGTA, $50 \mathrm{mM}$ ß-glycerol phosphate, $25 \mathrm{mM}$ $\mathrm{NaF}, 0.1 \mathrm{mM} \mathrm{Na} \mathrm{VO}_{4}, 1$ tablet $/ 50 \mathrm{ml}$ complete protease inhibitor cocktail (Roche) and $1 \mathrm{mM}$ phenylmethyl sulfonyl fluoride (PMSF). The immune-complexes were then incubated for $20 \mathrm{~min}$ at $30^{\circ} \mathrm{C}$ in $50 \mu 1$ of the kinase assay buffer supplemented with $1 \mu \mathrm{g}$ of histone H1 (Millipore).

Immunoblot analysis. Floating and adherent cells were harvested and washed with ice-cold PBS. Harvested cells were then solubilized with lysis buffer containing $20 \mathrm{mM}$ Tris (pH 7.5), 0.5\% Triton ${ }^{\circledR}$ X-100 (Bio-Rad Laboratories, Hercules, CA, USA), $2 \mathrm{mM} \mathrm{MgCl}$, $1 \mathrm{mM}$ dithiothreitol (DTT), $1 \mathrm{mM}$ EGTA, $50 \mathrm{mM}$ B-glycerophosphate, $25 \mathrm{mM} \mathrm{NaF}, 1 \mathrm{mM}$ $\mathrm{Na}_{3} \mathrm{VO}_{4}, 2 \mu \mathrm{g} / \mathrm{ml}$ leupeptin, $2 \mu \mathrm{g} / \mathrm{ml}$ pepstatin A, $2 \mu \mathrm{g} / \mathrm{ml}$ antipain and $1 \mathrm{mM}$ PMSF. After incubation on ice for $1 \mathrm{~h}$, insoluble materials were removed by centrifugation at $12,000 \mathrm{x} g$ for $15 \mathrm{~min}$, and protein concentrations were determined using the $\mathrm{BCA}^{\mathrm{TM}}$ protein assay reagent (Pierce, Rockford, IL, USA) according to the manufacturer's instructions. Each sample was resolved by SDS-polyacrylamide gel electrophoresis (SDS-PAGE) and electro-transferred onto a PVDF membrane (Millipore, Billerica, MA, USA). The 
A.

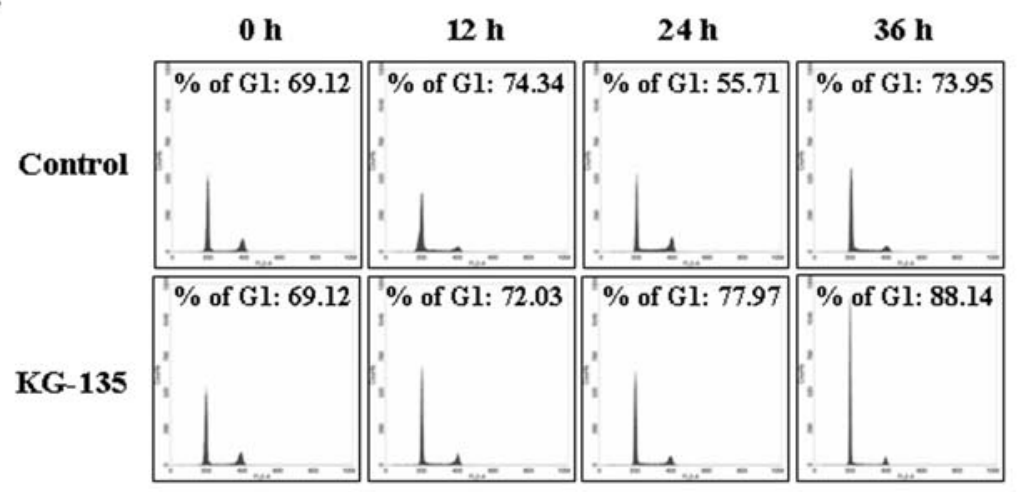

B.
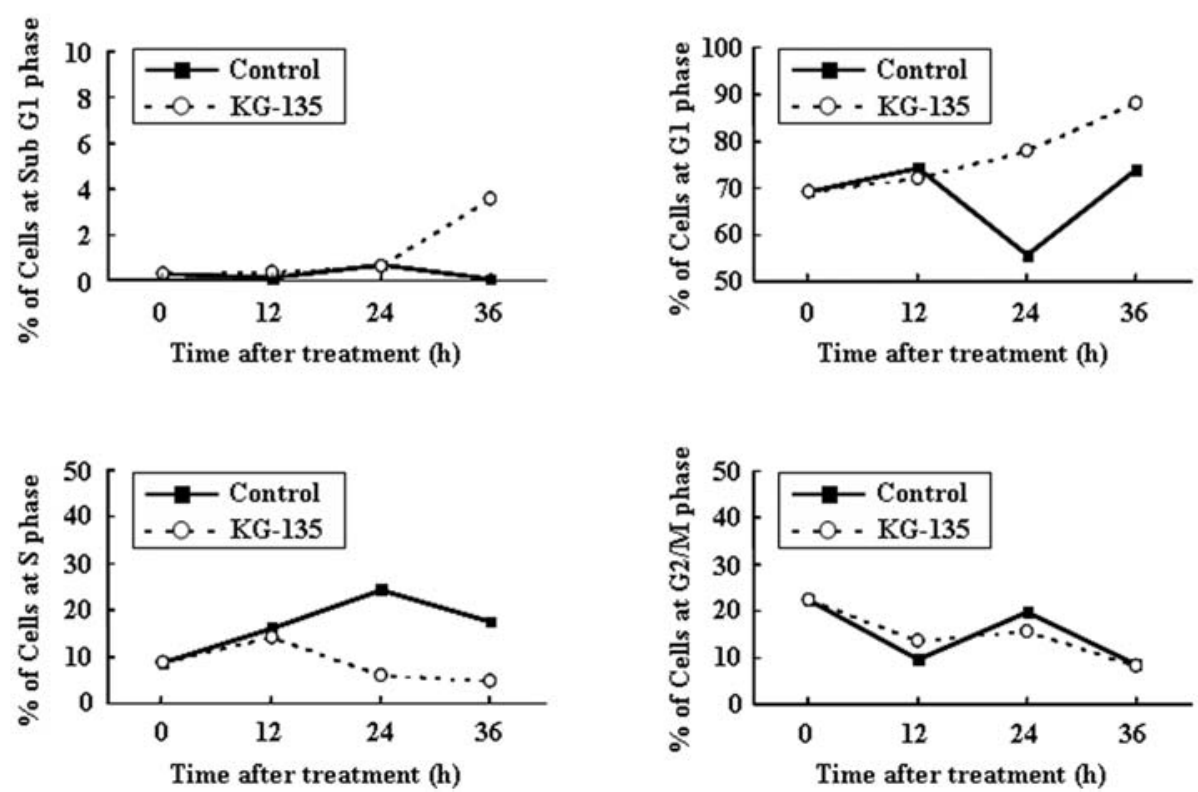

Figure 2. KG-135 treatment arrests cell cycle at G1 phase. (A) HeLa cells were plated at 7x105 cells per 100-mm dish and cultured in DMEM containing 5\% FBS, and were treated with or without $75 \mu \mathrm{g} / \mathrm{ml} \mathrm{KG-135}$ in DMEM. At $12 \mathrm{~h}$ intervals of KG-135 treatment, cells were trypsinized and fixed with $70 \%$ ethanol. Flow cytometric analysis was performed as described in Materials and methods. Percentages of cells in G1 phase were calculated and typed in a set of FACS plots. (B) Percentages of cells in each phase were calculated and plotted as a function of time duration of KG-135 treatment.

blotted membranes were blocked with $5 \%$ non-fat dry milk (Carnation $^{\circledR}$, Glendale, CA, USA) in PBS with $0.1 \%$ Tween-20 (PBST) at room temperature for $1 \mathrm{~h}$ and probed with specific antibodies. The probed blots were washed and incubated with a horseradish peroxidase-coupled anti-rabbit IgG (Pierce), and then visualized by ECL ${ }^{\mathrm{TM}}$ (GE Healthcare, UK).

Preparation of total RNA and reverse transcriptionpolymerase chain reaction $(R T-P C R)$ analysis. HeLa cells were plated at a density of $7 \times 10^{5}$ cells per $100 \mathrm{~mm}$ dish and cultured in DMEM containing 5\% FBS, and treated with $75 \mu \mathrm{g} / \mathrm{ml}$ of KG-135 in DMEM for intervals of 6 for $36 \mathrm{~h}$. The medium was then removed by aspiration and $1 \mathrm{ml}$ easyBlue $^{\mathrm{TM}}$ (Intron Biotechnology, Korea) reagent was added to each dish to lyse the cells. Total RNA extraction and reversetranscription were performed as described by the manufacturer.
The cDNA samples were amplified by polymerase chain reactions: $94^{\circ} \mathrm{C}$ for $1 \mathrm{~min}, 56^{\circ} \mathrm{C}$ for $1 \mathrm{~min}$, and $72^{\circ} \mathrm{C}$ for $1 \mathrm{~min}$, for 30 cycles. Amplified products were analyzed by $1.5 \%$ agarose gel electrophoresis, stained with ethidium bromide, and analyzed by GelDoc imaging system (Bio-RAD) under UV light.

\section{Results}

$K G-135$ arrests cells at the G1 phase of the cell cycle in HeLa cells. We first assessed whether KG-135 interfered with the proliferation of HeLa cells by performing the MTT assay. When HeLa cells were treated with various concentrations of KG-135 for 12, 24 and $36 \mathrm{~h}$, the cell viability was decreased in a time- and dose-dependent manner with an approximate $\mathrm{IC}_{50}$ value of $69 \mu \mathrm{g} / \mathrm{ml}$ (Fig. 1). 

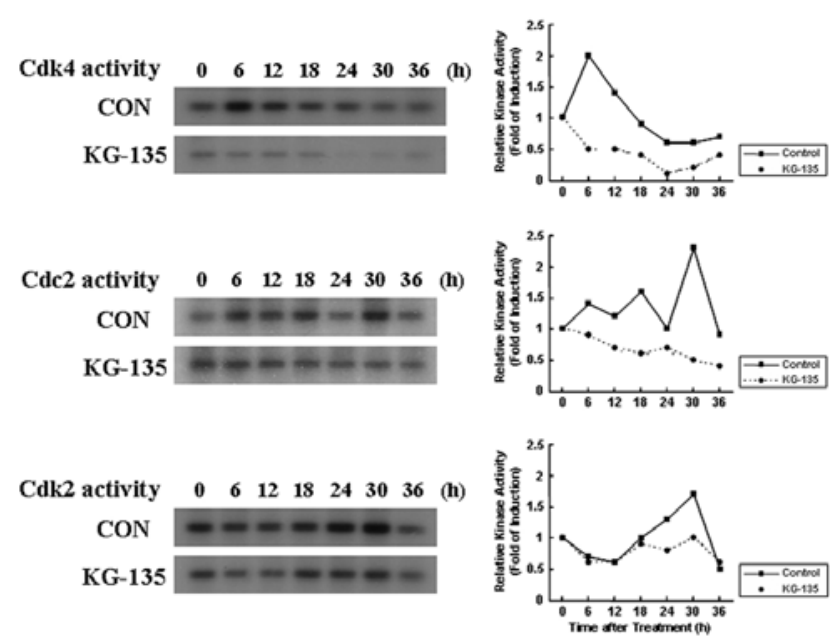

Figure 3. KG-135 treatment selectively inhibits Cdk4 and Cdc2 activities. (A) HeLa cells were incubated with or without $75 \mu \mathrm{g} / \mathrm{ml} \mathrm{KG-135}$ in DMEM for $36 \mathrm{~h}$, and cell lysates were prepared at 6-h intervals. Histone H1 kinase activity associated with immune-complexes precipitated by anti-Cdk4, $\mathrm{Cdc} 2$, and $\mathrm{Cdk} 2$ was determined as described in Materials and methods. Relative activities of each kinase were calculated by calibrated densitometer and plotted as a fold of induction.

To examine whether this decrease in cell viability was a consequence of cell cycle arrest at a specific phase or a consequence of cell death, we analyzed by flow cytometry the cell cycle of HeLa cells after treatment with KG-135. The results showed that cell growth was arrested at the G1 phase by treatment with $75 \mu \mathrm{g} / \mathrm{ml} \mathrm{KG-135}$. The proportion of cells in the G1 phase gradually increased $>88 \%$ of the total cells after $36 \mathrm{~h}$ of KG-135 treatment, while that in control cells changed in a cell cycle-dependent fashion from 55 to $74 \%$ (Fig. 2A). The results indicated that the cell populations in $\mathrm{S}$ phase and G2/M phase decreased by 4.77 and $8.09 \%$, respectively, after $36 \mathrm{~h}$ of KG-135 treatment (Fig. 2B). In addition, when cells were treated with KG-135 for $36 \mathrm{~h}$, caspase- 3 activity was not detectably activated (data not shown), although the sub G1 fraction was minimally elevated by $3.56 \%$, as compared to that of the untreated cells (Fig. 2B). These results indicate that KG-135 arrests the cells at the G1 phase of the cell cycle in HeLa cells.

Cdk4 and Cdc2 kinase activities are down-regulated in KG-135-treated HeLa cells. Since cell cycle arrest was induced at G1 phase in KG-135-treated cells, we examined whether KG-135 could induce the down-regulation of Cyclin/ Cdk activities that are responsible for cell cycle progression of G1 phase. The results indicated that Cdk4 and Cdc2 kinase activities were markedly down-regulated after $6 \mathrm{~h}$ of treatment

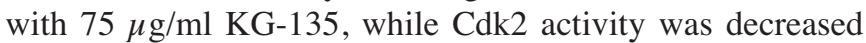
after $24 \mathrm{~h}$, as compared with the corresponding Cdk kinases activity in untreated control cells (Fig. 3).

These data indicate that KG-135-induced arrest of the cell cycle at G1 phase is associated with down-regulated Cdk4, $\mathrm{Cdc} 2$ and Cdk2 kinase activity in HeLa cells.

Down-regulation of Cdk activity is associated with reduced protein levels of Cyclins and Cdks and also with increased protein levels of Cdk inhibitors, $p 21^{\text {Wafl/Cipl }}$ and $p 27^{\text {Kipl }}$ in KG-135-treated HeLa cells. To investigate the possible mechanisms involved in the down-regulation of G1 Cyclindependent kinases activity in KG-135-treated HeLa cells, we first tested whether the down-regulated Cdk activities were temporally associated with altered protein levels of Cdks
A.

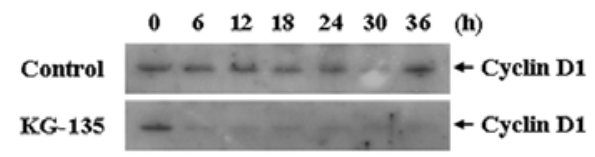

$\begin{array}{llllllll}0 & 6 & 12 & 18 & 24 & 30 & 36 & (h)\end{array}$

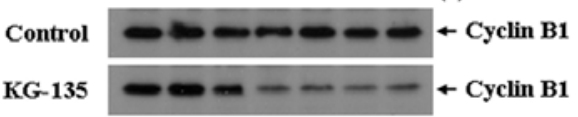

$\begin{array}{llllllll}0 & 6 & 12 & 18 & 24 & 30 & 36 & \text { (h) }\end{array}$

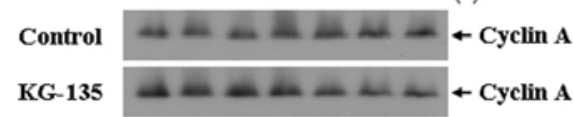

$\begin{array}{llllllll}0 & 6 & 12 & 18 & 24 & 30 & 36 & \text { (h) }\end{array}$

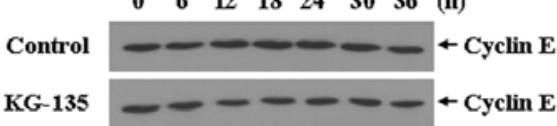

B.

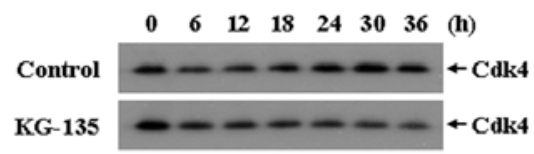

$\begin{array}{llllllll}0 & 6 & 12 & 18 & 24 & 30 & 36 & \text { (h) }\end{array}$

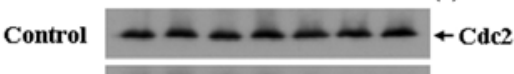

KG-135

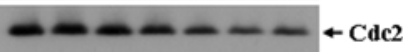

$\begin{array}{llllllll}0 & 6 & 12 & 18 & 24 & 30 & 36 & \text { (h) }\end{array}$

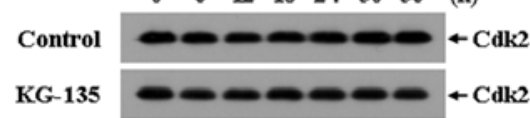

C.

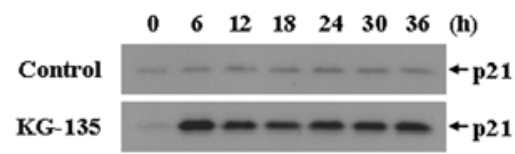

$\begin{array}{llllllll}0 & 6 & 12 & 18 & 24 & 30 & 36 & (h)\end{array}$

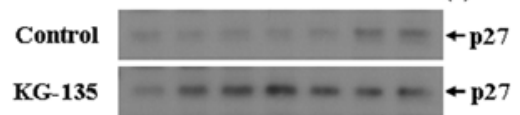

$\begin{array}{llllllll}0 & 6 & 12 & 18 & 24 & 30 & 36 & \text { (h) }\end{array}$

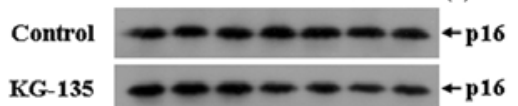

Figure 4. Protein levels of Cyclins and Cyclin-dependent protein kinases are decreased by KG-135 treatment in a time-dependent manner. (A) HeLa cells were treated with $75 \mu \mathrm{g} / \mathrm{ml} \mathrm{KG-135} \mathrm{in} \mathrm{DMEM} \mathrm{for} 36 \mathrm{~h}$, and cell lysates were prepared at $6 \mathrm{~h}$ intervals. Levels of Cyclin D1, B1, A and E in total cell lysate were determined by immunoblot analysis using anti-Cyclin D1, B1, A and E antibodies. (B) Levels of Cdk4, Cdc2 and Cdk2 were determined by immunoblot analysis using anti-Cdk4, Cdc2 and Cdk2 antibodies. (C) Levels of $\mathrm{p} 21^{\text {Wafl/Cip1 }}, \mathrm{p} 27^{\text {Kip1 }}$ and $\mathrm{p} 16^{\text {Ink4 }}$ were determined by immunoblot analysis using anti$\mathrm{p} 21^{\text {Wafl/Cip1 }},-$ $27^{\text {Kip } 1}$ and $-\mathrm{p} 16^{\text {Ink4 }}$ antibodies. 


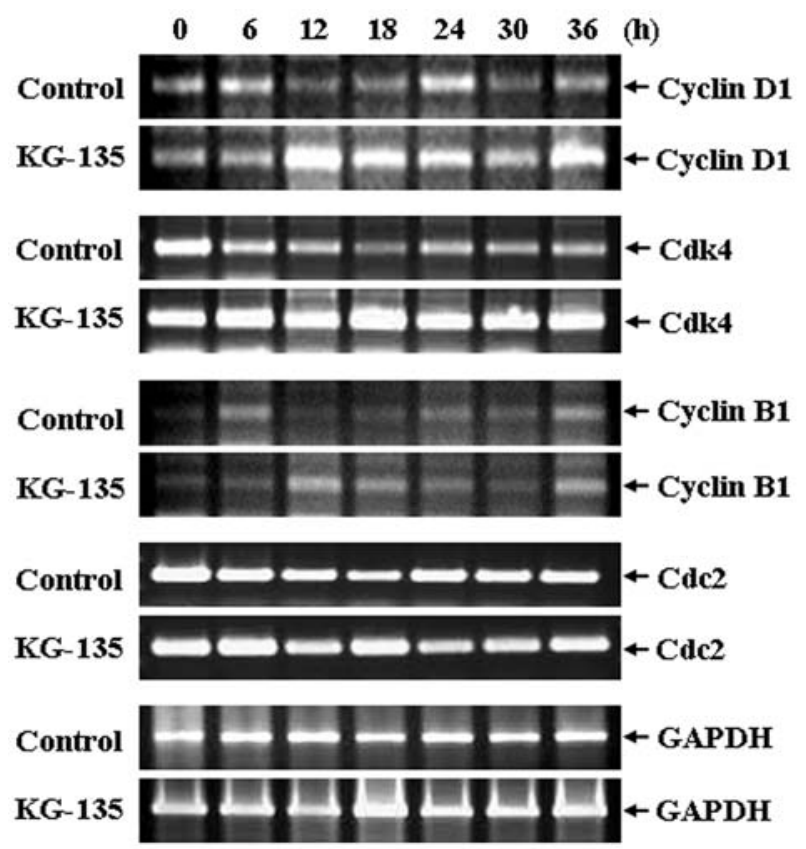

Figure 5. mRNA levels of Cyclin D1/Cdk4 and Cyclin B1/Cdc2 are not altered by KG-135 treatment. HeLa cells treated with $75 \mu \mathrm{g} / \mathrm{ml} \mathrm{KG-135}$ for $36 \mathrm{~h}$, and total mRNA was extracted from at 6-h intervals. cDNAs of each sample were prepared by reverse-transcription reaction, and $1 \mu \mathrm{g} / \mathrm{ml}$ of cDNAs were amplified by polymerase chain reaction (PCR) with specific primers for Cyclin D1, Cdk4, Cyclin B1 and Cdc2, as described in Materials and methods. PCR products of each gene were electrophoresed on a $1.5 \%$ agarose gel, and images of the gel were obtained by GelDoc imaging system.

complexes in cells after treatment with KG-135 (Fig. 4). The results from immunoblot analyses indicated that the intracellular protein levels of Cyclins D1 and B1 were markedly decreased after 6-12 $\mathrm{h}$ with KG-135, while the protein levels of Cyclins A and E were minimally altered (Fig. 4A). Moreover, the protein levels of $\mathrm{Cdk} 4$ and $\mathrm{Cdc} 2$ were also decreased after 6 and $18 \mathrm{~h}$ of treatment respectively, while the Cdk2 protein level remained unaltered (Fig. 4A and B). We also examined the intracellular protein levels of endogenous Cdk inhibitors, p2 $1^{\text {Waf1/Cip1 }}$, p2 $7^{\text {Kip } 1}$ and p16 $6^{\text {Ink4 }}$ in KG-135treated cells. The results indicated that the protein levels of $\mathrm{p} 21^{\mathrm{Waf} 1 / \mathrm{Cip} 1}$ and $\mathrm{p} 27^{\mathrm{Kip} 1}$ were dramatically increased over time from 6 to $36 \mathrm{~h}$ of treatment with KG-135, while the p16 $6^{\text {Ink4 }}$ protein level was not changed during the time course tested (Fig. 4C). We then investigated whether these decreases in the protein levels of Cyclins and Cdks might also occur at the transcriptional level in KG-135-treated cells. The results from reverse transcription-polymerase chain reaction (RTPCR) indicated that mRNA levels of Cyclin D1, Cdk4, Cyclin B1 and Cdc2 varied as the cells underwent cell cycle progression in untreated control cells (Fig. 5). In contrast, mRNA levels of Cyclin D1 and Cdk4 were markedly elevated and sustained throughout the time course in cells treated with KG-135, as compared to the mRNA levels of untreated control cells. The results showed that the mRNA levels of Cyclins D1 and B1, and Cdk4 and Cyclin B1 maximally increased by $48 \%(12 \mathrm{~h}), 65 \%(12 \mathrm{~h})$ and $55 \%(18 \mathrm{~h})$, respectively, while the mRNA level of $\mathrm{Cdc} 2$ decreased by $46 \%$ after $24 \mathrm{~h}$ of treatment.

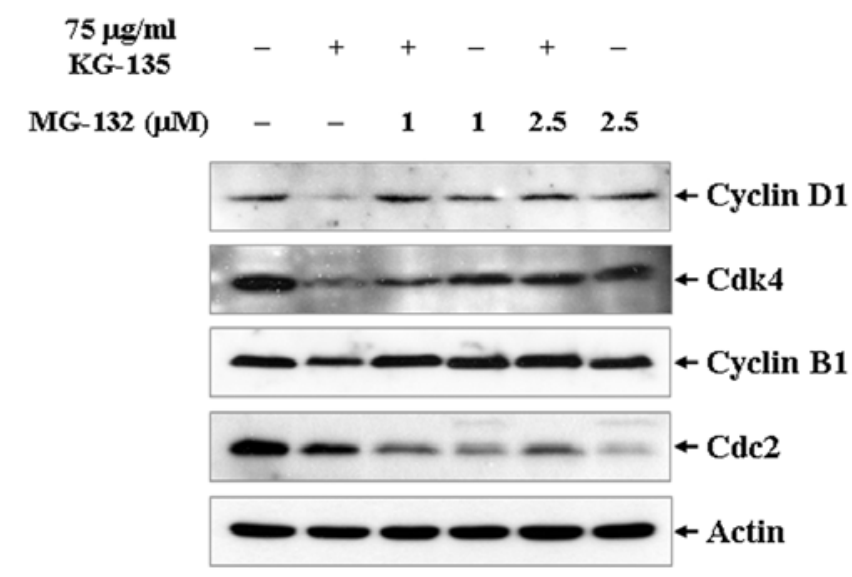

Figure 6. The proteasome inhibitor, MG-132, blocks KG-135-induced down-regulation of Cyclin D1, Cdk4 and Cyclin B1 protein in HeLa cells.

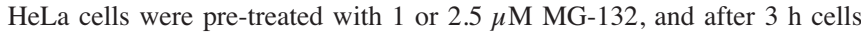
were washed with growth media. Cells were then treated with $75 \mu \mathrm{g} / \mathrm{ml} \mathrm{KG-}$ 135 for $24 \mathrm{~h}$. Thereafter, whole-cell extracts were prepared, and $50 \mu \mathrm{g}$ of protein was resolved on $12 \%$ SDS-PAGE, electrotransferred, and probed with anti-Cyclin D1, -Cdk4, -Cyclin B1, -Cdc2 and -actin as described in Materials and methods.

However, these changes in intracellular mRNA levels did not temporally correlate to the reduced intracellular protein levels of corresponding proteins in cells induced by treatment with KG-135.

These results indicate that $\mathrm{KG}$-135-induced downregulation of $\mathrm{Cdk} 4, \mathrm{Cdc} 2$ and $\mathrm{Cdk} 2$ kinase activities can be primarily attributed to respective decreases in intracellular protein levels and also, in part, to increased protein levels of endogenous Cdk inhibitors, $\mathrm{p} 21^{\mathrm{Waf} 1 / \mathrm{Cip} 1}$ and $\mathrm{p} 27^{\mathrm{Kip} 1}$. The results also indicated that decreases in protein levels of Cyclin D1, Cdk4, Cyclin B1 and Cdc2 in KG-135-treated cells may occur at the post-translational level.

Decreases in protein levels of Cyclin D1/Cdk4 and Cyclin B1 are efficiently blocked by co-treatment with $M G$-132, a proteasome inhibitor. We then investigated whether the KG-135-induced reduction of intracellular levels of Cyclin D1/ $\mathrm{Cdk} 4$ and $\mathrm{Cyclin} \mathrm{B} 1 / \mathrm{Cdc} 2$ was mediated by the proteasome pathway, by using MG-132, a potent, selective and reversible proteasome inhibitor. Pre-treatment of cells with MG-132 markedly prevented the KG-135-induced decreases in protein levels of Cyclin D1, Cdk4 and Cyclin B1 in a dose-dependent manner (Fig. 6). In contrast, the reduced protein level of Cdc2 in KG-135-treated cells was not prevented by pretreatment of cells with MG-132. The result also indicated that treatment of cells with MG-132 alone minimally affected the intracellular levels of these proteins. These data suggest that KG-135-induced decreases in the protein levels of Cyclin D1, Cdk4 and Cyclin B1, but not of Cdc2, are mediated by proteasome-mediated degradation in the KG-135 treated cells.

\section{Discussion}

The present study was aimed to investigate the mechanism by which KG-135, heat processed neoginseng, exerts its anti- 
proliferative effects in human cancer HeLa cells. Our results show that KG-135 induces cell cycle arrest at the G1 phase of HeLa cells by a mechanism that involves down-regulation of $\mathrm{Cdk} 4$ and $\mathrm{Cdc} 2$ kinase activities through the proteasomal degradation of Cyclin D1, Cdk4 and Cyclin B1.

There is evidence to suggest that the activity of Cyclindependent kinases is universally over-activated in human cancers. Thus, Cyclin-dependent kinases are thought to be good target molecules for developing anti-cancer drugs for various types of human cancers. Since it has been suggested that ginsenosides exert cytostatic or cytotoxic activities against various cancer cell types in culture and also in animal cancer models, it is important to understand how these agents arrest cell proliferation and consequently lead to apoptosis in cancer cells.

In our earlier studies, we showed that ginsenosides of the diol type, including Rg5, Rs3, Rs4, panaxadiol and Rh2 induce cell cycle arrest at lower doses, and apoptosis at higher doses (11,14,23-25). These diol-type ginsenosides share a common dammarane skeletal structure with - $\mathrm{OH}$ groups attached at C-3 and $\mathrm{C}-12$, but they play different functional roles in cell cultures (26). KG-135 is a heat-processed neoginseng produced to enrich the contents of diol-type ginsenosides which constitute roughly equal amounts of three ginsenosides, Rk1, Rg3 and Rg5. Earlier studies suggested that KG-135 exerts much higher cytostatic and cytotoxic effects against human cancer cells in cultures than do conventional red ginseng and white ginseng preparations. Rg5 has been shown to increase intracellular $\mathrm{p} 21^{\text {Waf } 1 / \text { Cip } 1}$ protein levels and also to down-regulate Cyclin E-dependent kinase activity, while Rs3 and Rs4 were shown to elevate protein levels of p53 and $\mathrm{p} 21^{\text {Waf } 1 / \mathrm{Cip} 1}$ and also to down-regulate Cyclins E- and A-dependent kinases activity in cell cultures $(11,23,24)$. Panaxadiol also selectively inhibits Cyclin A-dependent kinase activity by a mechanism associated with increased intracellular $\mathrm{p} 21^{\text {Waf } 1 / \text { Cip } 1}$ levels, while Rh2 induces cell cycle arrest at the G1/S boundary by down-regulating Cyclin E-dependent kinase activity, which may be associated with increased intracellular levels of p27 Kip1 $(14,25)$. When taken together with the results of other groups $(12,13,27)$, our results suggest that diol-type ginsenosides inhibit cell proliferation by arresting the cell cycle at G1 or G1/S phase by downregulating Cyclin-dependent kinase activities. However, the underlying mechanism of this down-regulation in cells treated with ginsenosides is still unknown. In this study, our results indicate that KG-135 induces cell cycle arrest at G1 phase in human cervix carcinoma HeLa cells. The cell population at G1 phase gradually increased to $88.14 \%$ of the total cells after $36 \mathrm{~h}$ of treatment, while those in $\mathrm{S}$ and $\mathrm{G} 2 / \mathrm{M}$ phase decreased by 8.09 and $4.77 \%$, respectively (Fig. 2A and B). After $36 \mathrm{~h}$, KG-135 treatment increased the number of cells in subG1 phase by $3.56 \%$, but it did not activate caspase- 3 activity in HeLa cells (data not shown). Thus, under these experimental conditions, KG-135 does not induce apoptotic cell death, but potently arrests the cells at the G1 phase of the cell cycle. The cell cycle arresting effect at the G1 phase is kinetically well correlated with down-regulation of the Cyclin-dependent kinase activities of Cyclin D1/Cdk4 and Cyclin B1/Cdc2 (Fig. 3). Cyclin E/Cdk2 activity was also down-regulated in the same cells, but the down-regulation kinetics did not correlate with cell cycle arrest at G1 phase, as the kinase activity was down-regulated after 24 h of KG-135 treatment. We found that the KG-135-induced down-regulation of these Cyclin-dependent kinases activity correlated well with the time-dependent decreases in protein levels of Cyclin D1, Cdk4, Cyclin B1 and Cdc2 in cells treated with KG-135 (Fig. 4A and B). It is interesting to note that the downregulation of Cyclin D1/Cdk4 and Cyclin B1/Cdc2 activity, but not Cyclin E/Cdk2 activity, also kinetically correlates with increased levels of $\mathrm{p} 21^{\mathrm{Waf} 1 / \mathrm{Cip} 1}$ and $\mathrm{p} 27^{\mathrm{Kip} 1}$ proteins in cells treated with KG-135 (Fig. 4C). Thus, the KG-135-induced down-regulation of $\mathrm{Cdk} 4$ and $\mathrm{Cdc} 2$ activity is likely to be due to the reduced intracellular levels of Cyclin D1/Cdk4 and Cyclin B1/Cdc2 complexes and also to the elevated protein levels of inhibitors $\mathrm{p} 21^{\text {Waf } 1 / \text { Cip } 1}$ and $\mathrm{p} 27^{\mathrm{Kip} 1}$.

These results support earlier studies suggesting that the anti-proliferating effect of ginsenoside $\operatorname{Rg} 5$ is related to down-regulation of Cyclin E-dependent kinase activity by increased protein levels of $\mathrm{p} 21^{\mathrm{Waf} 1 / \mathrm{Cip} 1}$ and to decreased protein levels of Cyclin E, Cdk2, and Cdc25A in human hepatocarcinoma cells (23). Moreover, ginsenoside $\mathrm{Rg} 1$, a diol-type ginsenoside, has been shown to block the cell cycle at G1 phase by a mechanism that is possibly associated with the down-regulation of Cyclin D1 levels and the up-regulation of intracellular levels of $\mathrm{p} 27^{\mathrm{Kip} 1}$, p $21^{\mathrm{Waf} 1 / \mathrm{Cip} 1}$ and $\mathrm{p} 53$ in human arterial vascular smooth muscle cells (28). These results indicate that diol-type ginsenosides, such as $\mathrm{Rg} 5, \operatorname{Rg} 1$, and $\mathrm{Rg} 3$, are able to block cells at the G1 phase of the cell cycle by down-regulating G1 Cyclin-dependent kinase activities. In addition, these diol-type ginsenosides are commonly able to down-regulate G1-Cyclin/Cdk activity by reducing the intracellular levels of the Cyclin-Cdk complexes and/or by increasing the levels of the Cyclin-Cdk inhibitor proteins, p2 $7^{\text {Kip } 1}$ and $\mathrm{p} 21^{\text {Waf1/Cip } 1 . ~ H o w e v e r, ~ d i o l-t y p e ~ g i n s e n o s i d e s ~}$ appear to differentially influence target molecules and their intracellular levels in cells. Since diol-type ginsenosides are able to down-regulate G1-Cyclin/Cdk activity by mechanisms that involve different target molecules, it has been suggested that a mixture of diol-type ginsenosides, such as KG-135 which contains roughly equal amounts of $\mathrm{Rk} 1, \mathrm{Rg} 3$, and $\operatorname{Rg} 5$, would be more effective in inhibiting the growth of cancer cells $(23,29-31)$. It is noteworthy that KG-135 downregulates G1 Cyclin/Cdk activity through multiple mechanisms that mediate decreases in the levels of Cyclins and Cdks and increases in the levels of Cyclin-Cdk inhibitor proteins, $\mathrm{p} 27^{\mathrm{Kip} 1}$ and $\mathrm{p} 21^{\mathrm{Waf} 1 / \mathrm{Cip} 1}$. The results indicate that diol-type ginsenosides in KG-135 exert additive effects, and down-regulate G1 Cyclin/Cdk activity through multiple combined mechanisms as described above.

We found that KG-135-induced degradation of Cyclins D1 and $\mathrm{B} 1$, and $\mathrm{Cdk} 4$ is effectively prevented by co-treatment with MG-132, a proteasome inhibitor, while the degradation of $\mathrm{Cdc} 2$ protein is not rescued by MG-132, indicating that the down-regulation of $\mathrm{Cdc} 2$ kinase activity is not associated with the proteasome pathway in KG-135-treated cells. In addition, the down-regulated Cdk2 activity does not correlate with proteasome-mediated degradation of Cyclin E and Cdk2 proteins, or with the inhibition kinetics of the cell cycle, since Cdk2 activity is down-regulated after $24 \mathrm{~h}$ of KG-135 treatment. Thus, KG-135 is able to arrest cells at the G1 
phase of the cell cycle by down-regulating the Cyclin $\mathrm{D} / \mathrm{Ckd} 4$ activity that is mediated through the proteasomemediated pathway. This is the first study to show that ginsenoside can induce the degradation of Cdk4, Cyclin B1 and Cyclin D1 via the proteasome-mediated pathway. Many studies have suggested that proteolysis of cell cycle regulators by the proteasome is essential for cell cycle progression or arrest in mammalian cells. For example, curcumin, a wellknown chemopreventive agent, has been shown to suppress proliferation of various cancer cells through proteasomemediated down-regulation of cyclin E (32), and rapamycin causes a G1 arrest in HER-2-overexpressing breast cancer cells that is associated with proteasome-mediated degradation of Cyclin D3 (33).

Our results also indicate that KG-135 induces elevation of the intracellular protein levels of $\mathrm{p} 21^{\mathrm{Waf} 1 / \mathrm{Cip} 1}$ and $\mathrm{p} 27^{\mathrm{Kip} 1}$. This KG-135-induced expression of CDK inhibitors correlates well in a time-dependent fashion with the down-regulated activity of Cdk4 and Cdc2. Thus, it is very likely that KG135-induced down-regulation of the G1-Cyclin/Cdk kinases activity is also significantly mediated by increased expression of the CDK inhibitors. Down-regulation of Cdc2 kinase activity in KG-135-treated cells is also likely to be associated with the elevated levels of the Cdk inhibitors in the cells.

Many investigators have invested substantial efforts to develop Cdk inhibitors as anti-cancer drugs on the basis of the fact that progression of many human cancers is associated with abnormal activation of Cdk activity. Since it has been difficult to develop selective Cdk inhibitors that inhibit a specific Cdk kinase activity, other attempts have been made to develop a pan Cdk inhibitor that could inhibit Cdk-activating kinases activity or increase the expression of endogenous Cdk inhibitor proteins, such as $\mathrm{p} 21^{\mathrm{Waf} 1 / \mathrm{Cip} 1}$ and $\mathrm{p} 27^{\mathrm{Kip} 1}$. We suggest that KG-135, a mixture of three diol-type ginsenosides, is a useful candidate for the treatment of human cancers, since it exhibits selective down-regulation of G1-Cyclin/Cdk kinases activity through the proteosome pathway and induces the expression of Cdk inhibitor proteins.

\section{Acknowledgements}

We thank Ginseng Science Corporation (Seoul, Korea) for donation of KG-135 and this work was supported by grant A04-0021-AK1101-07A4-00040B (2007) from fund M10104000129-02J0000-05910 from the Ministry of Health and Welfare, Korea (to S.K.L.).

\section{References}

1. Shapiro GI: Cyclin-dependent kinase pathways as targets for cancer treatment. J Clin Oncol 24: 1770-1783, 2006.

2. Bruce A, Edgar TL and Terry LO: Endoreplication cell cycles: more for less. Cell 105: 297-306, 2001.

3. Grana X and Reddy EP: Cell cycle control in mammalian cells: role of cyclins, cyclin dependent kinases (CDKs), growth suppressor genes and cyclin-dependent kinase inhibitors (CKIs). Oncogene 11: 211-219, 1995.

4. Hunter T: Braking the cycle. Cell 75: 839-841, 1993

5. Fischer PM and Lane DP: Inhibitors of cyclin-dependent kinases as anti-cancer therapeutics. Curr Med Chem 7: 1213-1245, 2000.

6. Baek NI, Kim DS, Lee YH, Park JD, Lee CB and Kim SI Ginsenoside Rh4: a genuine damarane glycoside from Korean red ginseng. Planta Med 62: 86-87, 1996.
7. Kubo M, Tong $\mathrm{CN}$ and Matsuda $\mathrm{H}$ : Influence of $70 \%$ methanolic extract from red ginseng on the lysosome of tumor cells and on the cytocidal effect of mitomycin C. Planta Med 58: 424-428, 1992.

8. Matsunaga H, Katano M, Saita T, Yamamoto H and Mori M: Potentiation of cytotoxicity of mitomycin $\mathrm{C}$ by a polyacetylenic alcohol, panaxytriol. Cancer Chemother Pharmacol 33: 291-297, 1994.

9. Wakayabashi C, Murakami K, Hasegawa H, Murata J and Saiki I: An intestinal bacterial metabolite of ginseng protopanaxadiol saponins has the ability to induce apoptosis in tumor cells. Biochem Biophys Res Commun 246: 725-730, 1998.

10. Yano H, Mizoguchi A, Fukuda K, Haramaki M, Ogasawara S, Momosaki S and Kojiro M: The herbal medicine sho-saiko-to inhibits proliferation of cancer cell lines by inducing apoptosis and arrest at the G0/G1 phase. Cancer Res 54: 448-454, 1994.

11. Kim SE, Lee YH, Park JH and Lee SK: Ginsenoside-Rs4, a new type of ginseng saponin concurrently induces apoptosis and selectively elevates protein levels of p53 and p21 $1^{\mathrm{WAF} 1}$ in human hepatoma SK-HEP-1 cells. Eur J Cancer 35: 507-511, 1999.

12. Oh M, Choi YH, Choi S, Chung H, Kim K, Kim SI, Kim DK and Kim ND: Anti-proliferating effects of ginsenoside Rh2 on MCF-7 human breast cancer cells. Int J Oncol 14: 869-875, 1999.

13. Cheng CC, Yang SM, Huang CY, Chen JC, Chang WM and Hsu SL: Molecular mechanisms of ginsenoside Rh2-mediated G1 growth arrest and apoptosis in human lung adenocarcinoma A549 cells. Cancer Chemother Pharmacol 55: 531-540, 2005

14. YH, Choi J, Shin S, Lee KY, Park JH and Lee SK: Panaxadiol selectively inhibits cyclin A-associated Cdk2 activity by elevating $\mathrm{p} 21^{\mathrm{WAF} / \mathrm{CIP1} 1}$ protein levels in mammalian cells. Carcinogenesis 24 : 1767-1772, 2003

15. Kang KA, Kim YW, Kim SU, Chae S, et al: G1 phase arrest of the cell cycle by a ginseng metabolite, compound $\mathrm{K}$, in U937 human monocytic leukamia cells. Arch Pharm Res 28: 685-690, 2005.

16. Yun TK: Experimental and epidemiological evidence of the cancer preventive effects of Panax ginseng C.A. Meyer. Nutr Rev 54: S71-S81, 1996.

17. Yun TK and Choi SY: Preventive effect of ginseng intake against various human cancers: a case control study on pairs, Cancer Epidemiol Biomarkers Prev 4: 401-408, 1995.

18. Wang CZ, Aung HH, Ni M, Wu JA, Tong R, Wicks S, He TC and Yuan CS: Red American ginseng: ginsenoside constituents and antiproliferative activities of heat-processed panax quinquefolius roots. Planta Med 73: 669-674, 2007.

19. Yun TK, Lee YS, Lee YH, Kim SI and Yun HY: Anticarcinogenic effect of Panax ginseng C.A. Meyer and identification of active compounds. J Korean Med Sci 16: S6-S18, 2001.

20. Keum YS, Park KK, Lee JM, Chun KS, Park JH, Lee SK, Kwon $\mathrm{H}$ and Surh YJ: Anti-oxidant and anti-tumor promoting activities of the methanol extract of heat-processed ginseng. Cancer Lett 150: 41-48, 2000

21. Park SA, Kim EH, Na HK and Surh YJ: KG-135 inhibits COX-2 expression by blocking the activation of JNK and AP-1 in phorbol ester-stimulated human breast epithelial cells. Ann NY Acad Sci 1095: 545-553, 2007.

22. Keum YS, Han SS, Chun KS, Park KK, Park JH, Lee SK and Surh YJ: Inhibitory effects of the ginsenoside Rg3 on phorbol ester-induced cyclooxygenase-2 expression, NF-kappaB activation and tumor promotion. Mutat Res 523-524: 75-85, 2003.

23. Lee KY, Lee YH, Kim SI, Park JH and Lee SK: GinsenosideRg5 suppresses cyclin E-dependent protein kinase activity via up-regulating $\mathrm{p} 21^{\mathrm{Cip} / \mathrm{WAF} 1}$ and down-regulating cyclin E in SKHEP-1 cells. Anticancer Res 17: 1067-1072, 1997.

24. Kim SE, Lee YH, Park JH and Lee SK: Ginsenoside-Rs3, a new diol-type ginseng saponin, selectively elevates protein levels of p53 and p21 WAF1 leading to induction of apoptosis in SK-HEP-1 cells. Anticancer Res 19: 487-491, 1999.

25. Lee KY, Park JA, Chung E, Lee YH, Kim SI and Lee SK: Ginsenoside-Rh2 blocks the cell cycle of SK-HEP-1 cells at the G1/S boundary by selectively inducing the protein expression of p27 Kip1. Cancer Lett 110: 193-200, 1996.

26. Shibata S: Chemistry and cancer preventing activities of ginseng saponins and some related triterpenoid compounds. J Korean Med Sci 16: S28-S37, 2001.

27. Ota T, Maeda M, Odashima S, Ninomiya-Tsuji J and Tatsuka M: G1 phase-specific suppression of the Cdk2 activity by ginsenoside Rh2 in cultured murine cells. Life Sci 60: PL39-PL44, 1996. 
28. Zhang HS and Wang SQ: Ginsenoside Rg1 inhibits tumor necrosis factor-alpha (TNF-alpha)-induced human arterial smooth muscle cells (HASMCs) proliferation. J Cell Biochem 98: 1471-1481, 2006.

29. Park IH, Kim NY, Han SB, Kim JM, Kwon SW, Kim HJ, Park MK and Park JH: Three new dammarane glycosides from heat processed ginseng. Arch Pharm Res 25: 428-432, 2002.

30. Park IH, Piao LZ, Kwon SW, Lee YJ, Cho SY, Park MK and Park JH: Cytotoxic dammarane glycosides from processed ginseng. Chem Pharm Bull 50: 538-540, 2002.

31. Popovich DG and Kitts DD: Structure-function relationship exists for ginsenosides in reducing cell proliferation and inducing apoptosis in the human leukemia (THP-1) cell line. Arch Biochem Biophys 406: 1-8, 2002.
32. Aggarwal BB, Banerjee S, Bharadwaj U, Sung B, Shishodia S and Sethi G: Curcumin induces the degradation of cyclin $\mathrm{E}$ expression through ubiquitin-dependent pathway and upregulates cyclin-dependent kinase inhibitors p21 and p27 in multiple human tumor cell lines. Biochem Pharmacol 73: 1024-1032, 2007.

33. García-Morales P, Hernando E, Carrasco-García E, MenéndezGutierrez MP, Saceda M and Martínez-Lacaci I: Cyclin D3 is down-regulated by rapamycin in HER-2-overexpressing breast cancer cells. Mol Cancer Ther 5: 2172-2181, 2006. 